\title{
Biomarkører ved demens
}

Engelsk oversettelse av hele artikkelen på www.tidsskriftet.no

I dag lever rundt 70000 personer med demenssykdom, men det er forventet en dobling i løpet av få år. Derfor vil utgiftene til demensomsorg i sykehjem om 40 år mer enn dobles fra dagens 18 milliarder dersom vi ikke får en ny og revolusjonerende behandling (1). Men til tross for stor oppmerksomhet rundt lidelsen de siste 20 årene, forblir halvparten av pasientene udiagnostisert (2). Dette kan ha mange årsaker. Manglende objektive kriterier i tillegg til manglende diagnostisk erfaring hos mange leger er to viktige grunner. Den hyppigste formen for demens er Alzheimers sykdom, som rammer $60-70 \%$ av pasientene. Det er i det siste kommet holdepunkter for at den prekliniske fasen pågår i mange år forut for symptomdebut, men ikke gir kliniske symptomer fordi hjernens kognitive reservekapasitet kompenserer for en tiltakende akkumulering av nevropatologiske forandringer (3).

I de senere år har det vært nedlagt betydelige ressurser for å påvise og utvikle objektive markører til bruk i diagnostikk ved demenssykdommer, i både den asymptomatiske og den symptomatiske fasen. Det dreier seg i første rekke om ulike former for MR-teknikker og spinalvæskemarkører (4), men også PET-undersøkelser av hjernen og endringer i blodet er aktuelle forskningsområder (3). En rekke studier har vist at det skjer en endring i mengden av proteinene («demensmarkørene») betaamyloid, total tau og fosforylert tau i spinalvæske ved Alzheimers demens (4). Betaamyloid antas å indikere forekomst av amyloide plakk i hjernen, total tau er en markør for nevrodegenerasjon, mens fosforylert tau sannsynligvis er relatert til forekomst av nevrofibrillære floker (tangles). Forandringene kan komme tidlig, til dels i asymptomatisk fase. Dette gjenspeiles i Dubois-kriteriene fra 2007 for Alzheimers sykdom, som til forskjell fra tidligere kriterier inkluderer både MR-forandringer og endringer i spinalvæskemarkører (5). Kriteriene krever at det foreligger redusert episodisk hukommelsesfunksjon samt enten medial temporallappsatrofi på MR-undersøkelse av hjernen, forandringer $i$ en eller flere av spinalvæskemarkørene, typiske forandringer på PET-undersøkelse eller en genetisk mutasjon (5).

Imidlertid er det gitt uttrykk for tvil om hvor nyttige kriteriene er i klinisk praksis (6). Nylig ble det publisert forslag til diagnostiske retningslinjer for demens av Alzheimers type (7). Der hevdes det at hos personer som møter de kliniske kriteriene kan biomarkører i spinalvæske øke den diagnostiske sikkerheten. Forfatterne anbefaler likevel ikke bruk av biomarkører i rutinediagnostikken - fordi: De kliniske kriteriene medfører meget god diagnostisk presisjon hos de fleste, det trengs mer forskning for å sikre at kriteriene som inkluderer bruk av biomarkører er tilstrekkelig utformet, det er begrenset standardisering mellom ulike laboratorier og tilgangen til biomarkører er begrenset i førstelinjetjenesten.

Ved Hukommelsesklinikken deler vi denne skepsisen og mener at demens foreløpig primært er en klinisk diagnose. Vi har flere eksempler på at pasienter med åpenbar kognitiv svikt der sykehistorie og kliniske symptomer er forenlig med demens av Alzheimers type, får påvist normale markører i spinalvæske eller har normale funn på MR-undersøkelse. Dette støttes av en svensk studie (6). Vår erfaring er at negative markører ikke utelukker demens, men at positive markører støtter den kliniske diagnosen.

Et annet komplisert felt er differensialdiagnostikk mellom de ulike demenssykdommene. De kliniske symptomene er til dels overlappende ved ulike sykdommer som fører til demens, og i flere studier har man påvist uventede nevropatologiske funn i forhold til klinisk fenotype. Det er derfor interessant å lese Skogseth og medarbeideres artikkel i dette nummer av Tidsskriftet. Den omhandler nytten av biomarkører i spinalvæske for å skille demens av Alzheimers type fra andre demensformer (8). De påviser relativt høy sensitivitet og spesifisitet ved bruk av spinalvæskemarkører, men konkluderer med at det ikke er nok holdepunkter for at markører alene kan skille demenstypene. Pasientene som er inkludert i de ulike studiene artikkelen bygger på, er undersøkt i en moderat eller fremskreden fase av sykdommen, da differensialdiagnostikk fremstår som mindre viktig.

I dag trenger vi først og fremst å kunne skille mellom de ulike demenssykdommene for å vurdere progredieringshastighet og type legemiddelbehandling samt at det ved noen demenssykdommer foreligger økt følsomhet for enkelte legemidler. I fremtiden vil det kanskje foreligge mer spesifikk antidemensbehandling, da vil det være vesentlig å skille mellom de ulike formene.

Demens er kanskje vår tids største folkesykdom og koster enormt i lidelse og kroner. Det er derfor av største viktighet å fortsette innsatsen når det gjelder utvikling av biomarkører for å lette diagnostikken ved klinisk demenssykdom, men også når det gjelder biomarkører i asymptomatisk fase. Så lenge vi ikke har effektive forebyggende behandlingsformer, vil slik tidligdiagnose riktignok ha begrenset nytteverdi. På den annen side - preklinisk diagnose vil presse frem krav om mer forebyggende behandling og kunnskap om årsaksforhold. Det er derfor svært viktig å øke forskningsinnsatsen på disse områdene.

\section{Anne Brækhus}

anne.braekhus@ous-hf.no

Anne Brækhus (f. 1961) er dr.med., spesialist i nevrologi og overlege ved Geriatrisk avdeling, Hukommelsesklinikken, og Nevrologisk avdeling, Oslo universitetssykehus, Ullevål.

Ingen oppgitte interessekonflikter.

\section{Litteratur}

1. Hjort PF, Waaler HT. Demens frem mot 2050. Tidsskr Nor Legeforen 2010; 130 $1356-8$

2. Lystrup LS, Lillesveen B, Nygård AM et al. Omsorgstilbud til hjemmeboende personer med demens. Tidsskr Nor Lægeforen 2006; 126: 1917-20.

3. Gustaw-Rothenberg K, Lerner A, Bonda DJ et al. Biomarkers in Alzheimer's disease: past, present and future. Biomark Med 2010; 4: 15-26.

4. Ballard C, Gauthier S, Corbett A et al. Alzheimer's disease. Lancet 2011; 377 1019-31.

5. Dubois B, Feldman HH, Jacova $\mathrm{C}$ et al. Research criteria for the diagnosis of Alzheimer's disease: revising the NINCDS-ADRDA criteria. Lancet Neurol 2007; 6: $734-46$.

6. Oksengard AR, Cavallin L, Axelsson R et al. Lack of accuracy for the proposed «Dubois criteria» in Alzheimer's disease. A validation study from the Swedish brain power initiative. Dement Geriatr Cogn Disord 2010; 30: 374-80.

7. McKhann GM, Knopman DS, Chertkow $\mathrm{H}$ et al. The diagnosis of dementia due to Alzheimer's disease: recommendations from the National Institute on Aging and the Alzheimer's Association workgroup. Alzheimers Dement 2011; 7: 263-9.

8. Skogseth R, Fladby T, Mulugeta E et al. Biomarkører i spinalvæske ved demens. Tidsskr Nor Legeforen 2011; 131: 2235-8. 